\title{
Process Approach to Management Knowledge Objects Managerial Expertise for Distance Learning
}

\author{
Krzysztof Hauke \\ Wroclaw University of Economics \\ Komandorska 118/120, \\ 53-345 Wrocław, Poland \\ Email: krzysztof.hauke@ue.wroc.pl
}

\begin{abstract}
One of the basic features of the information society is a constant acquisition of information. This information can be obtained from various sources. One source is the Internet environment. In this environment, you can use the standard communication of information on the web. The disadvantage of this approach is the lack of assessment of knowledge by the recipient. If you want to professionally lead the learning process then we have to use distance learning technologies. The use of distance learning systems, forcing the recipient to the following activities: acquire new knowledge and its evaluation. Note, however, that the knowledge in the course offered must be current. Then it makes sense to use distance learning systems.

The paper will be presented process approach to management knowledge objects managerial expertise for distance learning systems. Process management is carried out in the following steps. knowledge acquisition, knowledge Locating, developing knowledge, preservation of knowledge, knowledge sharing, knowledge utilization. The use of learning objects taking into account the process approach to improving the quality of the courses offered in the form of e-learning.
\end{abstract}

Keywords: e-learning, knowledge, knowledge management, knowledge object, knowledge management process approach.

\section{INTRODUCTION}

The traditional model of the teacher - student knowledge transfer becomes quite a big limitation. The limitation is due to lack of time and logistic reasons. However, keep in mind that this model is good especially when you consider news aspect of their contents. In order to try to alleviate the constraints are involved with information technology solutions such as e-learning. From the point of view of the process of communicating, content society is already so educated, that it does not have much of a problem. The problem, however, lies in the interior of such a system. Didactic units are created by traditional human team. Immediately after completion of the work related to the availability of content is generally rated very well. However, after some time, a substantive assessment related to the content will be increasingly lower until it can be quite inadequate to the environment and the existing state of knowledge in the field. In order to avoid this uncomfortable situation a didactic unit or course must be constantly evaluated. Any derogation as to the content on a regular basis must be corrected to prevent such a situation that learners will use the outdated knowledge without this awareness. However, to improve the content can not be consistently implemented from the outset. Such an approach leads to a significant prolongation update the content of the course. The speed associated with upgrading the content is inherent to the process of knowledge management. If you consider elements of knowledge management in this course including activities associated with the creation or update it, will no longer be time-consuming. Note, however, that implemented elements of knowledge management in elearning systems will not eliminate the traditional mentor in preparation for the actual content of educational material [1] [2].

\section{LEARNING OBJECTS IN EDUCATIONAL MATERIALS}

The information society is a new type of society, which is characterized by information processing. One of the sectors which is engaged in information processing is education. Traditionally provided education requires challenges for mentors returning knowledge through lectures, exercises, conservatories and laboratories. Progressive growth of information generated by the various institutions of this society compels members to look into the issue of the organization of knowledge. In the eighties of the last century we had seen very rapid growth in the use of information technology in teaching [3]. Mentors began to prepare classes with the use of tools. It was noted unsatisfactonary with these solutions related to the teaching process. There were tools (course management systems), which in a comprehensive manner solved the problems of teaching. However, even here there are problems. Each of the mentors worked out on an individual didactic material for the course. The development of such a course would be individual to the issue and was of the author. In addition, be aware of the dynamics of the environment from the point of view:

- time that provides more and more information in the following units of time,

- a place that generates information specific to their environment.

But the uniqueness of feature associated with the time to create such a course. The preparation of such teaching 
material that takes into account any change of scene and adjusts to the time and place is very difficult. This problem can be solved by developing courses using the components. Components of the so-called learning objects (learning object - LO). The concept of learning objects was first described in the work of Gerard in 1967. Initially, this concept does not use the term object of knowledge. The first time the concept of learning object was used 1994 by Wayne Hodgins, who created a working group Computer Education Management Association (CEdMa) dealing with objects of knowledge [12].

In the literature you can find many definitions of learning objects.

General Definition - the object of knowledge is any element constituting a whole (entity) in digital form or not, which can be used in the process of learning, teaching or training.

This learning object is the smallest independent structural elements comprising three components:

- purpose - specifying expected outcomes of learning / teaching;

- activity - that this part of the knowledge element, which achieves the objective pursued;

- evaluation - allows an indication of how the expected objective has been achieved.

According to Mr Shepherd - the object of knowledge is a small, digital reusable component that can be used - alone or in combination with others - using computer software by the creator of the content or independently by the learner, for educational purposes [5].

According to S. Mills - the object of knowledge can be used to meet the teaching and the intended results can be borrowed from a different educational environment. Knowledge reusable objects are associated with electronic educational sources that can be used by different learning environments [14].

Definition author - learning objects are self-contained and independent objects that describe a reality that can be used an infinite number of times in various educational courses.

The creation of such an object is very difficult. Creating a learning object should take into account quality of universality. This will ensure that the use of such a universal object in other educational materials.

The object of knowledge is an independent piece of information, which might function independently, designed for reuse, used to create a lecture held at a distance. The object of knowledge is associated with:

- content / object content,

- metadata (tags) that describe the object keywords,

- educational material management systems LMS /

LCMS (Learning Management System / Learning Content Management System).

The figure below (Fig. 1) shows the relationship between the object of knowledge, metadata and educational material management systems.

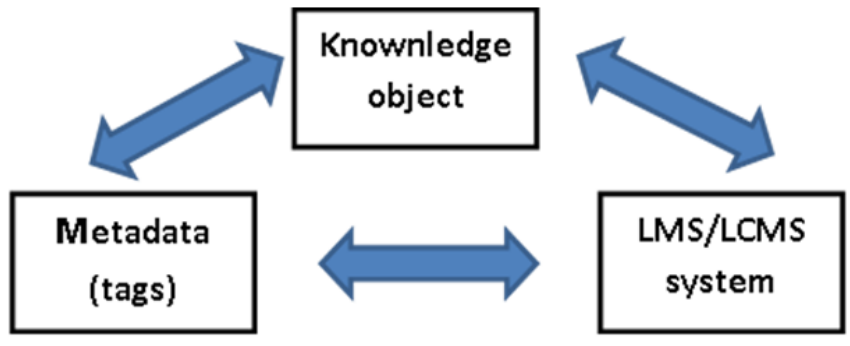

Fig. 1. Environment the object of knowledge

Source: Own study based on: http://www.itpedia.pl/ index.php/Grafika:E-lear_5.jpg

From the above considerations the common elements of knowledge object definition can be derived::

- content - the purpose of training, content and actions in the area of knowledge transfer needed to achieve this goal and objective assessment reflecting the training,

- size or time needed to take advantage of knowledge party knowledge that assimilation takes no more than 15 minutes,

- context and characteristics - knowledge that can operate independently and be delivered to the listener, if necessary, exactly on time and in sufficient quantity,

- labeling and remembering - the part of knowledge that describes a standardized set of tags.

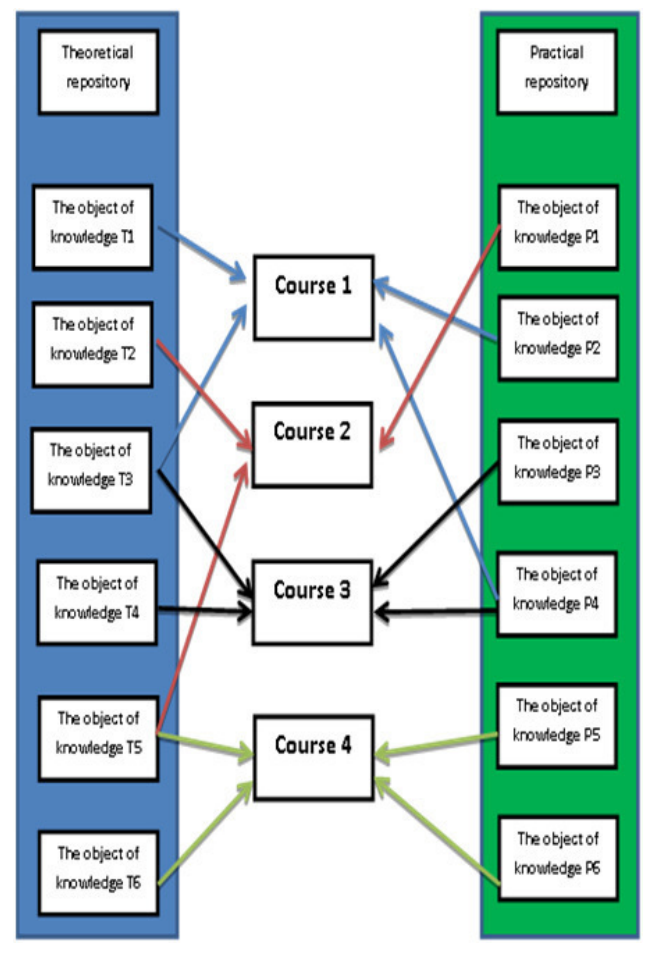

Fig. 2. Schematic combining learning objects into a finished course

Source: Own study based on http://www.itpedia.pl/ index.php/Grafika:E-lear_6.jpg 
The object of knowledge can be represented by: text, graphic image, animation, multimedia audio, video [4]. a combination of these elements [13].

Learning objects are managed via the Learning Management System (LMS). Learning objects can be grouped into thematic repositories individually determined by the management of these facilities.

Repository - the place for orderly storage of documents, all of which are designed for sharing. The concept identified with the main storage, the central, but designed in such a way that access to all of its resources was equally easy. In the era of information technology there is also a term used in relation to all sorts of digital resources (databases, set of packages or source code), for example on the Internet [14].

Repository relates primarily to storage, and no sharing. It is a storage at the same time: the main, central, current and easily accessible.

Knowledge repository - a repository of documents with specific subject matter, with a specific to the field of mechanisms that facilitate access to information, or / and mechanisms for synthesizing additional information based on content stored documents.

Repository of domain, also called thematic repository and the repository of knowledge, according to. Lexicon Distance learning: the repository is a storage place structured domain knowledge, intended for repeated use in different contexts. Knowledge is presented in the form of a portion called - LO (Learning Object) In other words, it is a specialized computer system, which performs the functions of storing, sharing and modifying structured domain knowledge.

Features a repository of knowledge

- completeness - chronological, thematic, etc,

- timeliness - the new data may change old,

- relationships - mapped data relationships,

- searchability - FTS, taxonomies,

- $\quad$ accessibility - digital form, the Internet, PDAs, Epaper.

In the picture above (Fig. 2) learning objects are divided into two repositories:

- practical (Pn) - contains objects resulting from the observation of reality, case studies, calculations, collected empirical material

- theoretical (Tn) - contains objects resulting from the theory related to the matter, definitions, concepts, structure, interpretations, which are contained in the books, published in the form of compact or posted on websites.

This approach allows the use of multiple learning object developed in various courses. It was only at the stage of designing the course designer can benefit from such a facility in order to obtain a particular course.

\section{THE EVOLUTION OF KNOWLEDGE}

The organization of the knowledge allows you to achieve new opportunities. Accordingly the strategy of its organization can contribute to a rapid response to stimuli from the environment. The strategy becomes a tool for organizing the accumulated knowledge from a particular individual. Be aware of the fact that the ordering of knowledge should be fully aware of the act and the result of a desire to dominate over its generation by a number of individual and collective objects. Mastering the body of knowledge related to the functioning of the matter may become the primary factor leading to success. We must realize that today's information society generates enormous amount of information even in the smallest unit of time. Organizing them as a whole would be an extremely difficult issue to pursue. Information technology organization is trying to help this knowledge as a whole. You can mention the concept of big data, which lets you store knowledge objects. At present, it is a challenge for the information society, which must determine the direction of its activities for the coming years. Currently, a better solution is to adopt a strategy for organizing knowledge in very limited areas, resulting from specialization. Such organized knowledge will be useful for potential people who would want to solve the problems of an individual or for the environment. Such an approach requires a focus on a very narrow area of activity. This leads to specialization of an individual or collective entity in the field of influence. The limited approach to knowledge organization for the area allows you to assign its high utility value. The big economic corporations using so organized knowledge can make decisions of a strategic nature. Of course, because of the dynamics of the environment when making strategic decisions should take into account current knowledge and adapt in activities that may result in the future.

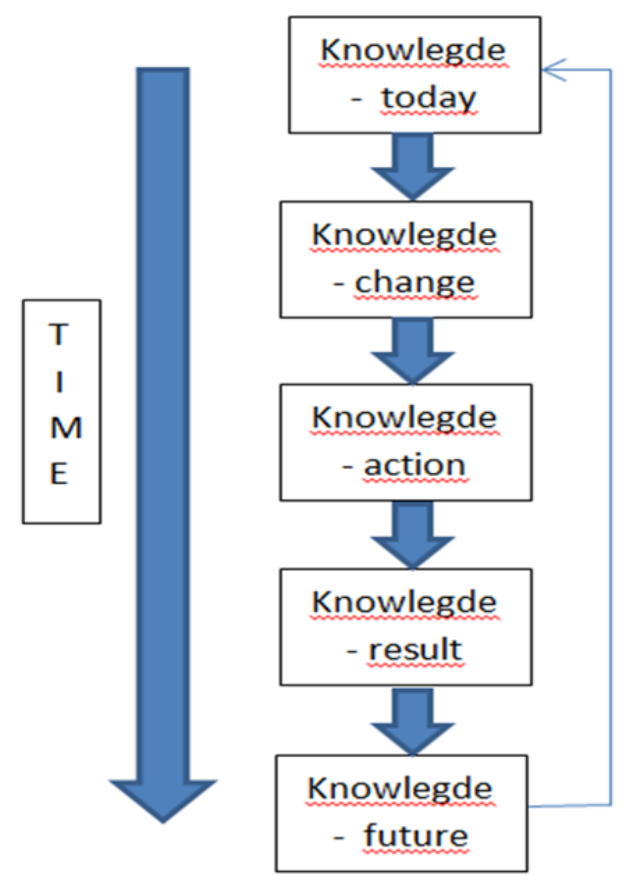

Fig. 3. The evolution of knowledge

Source: Own study 
The process of evolution of knowledge is dependent on time. In the figure above (Fig. 3) the process of evolution is shown in five steps:

- Knowledge today - it is the state of knowledge on a specific state of our reality.

- Change of knowledge - a process based on the fact that by comparing the state of knowledge in the information system with real environment arising.

- Action on knowledge - declare that appeared in the environment or you may receive new knowledge forces administrators to system.

- Measurement of knowledge - at this stage the control of the state of knowledge in the information system of the update knowledge of the environment.

- Knowledge in future - it reaches the result of this step is to ensure comparability of knowledge in the system and the knowledge derived from the environment. After this stage, your "future" knowledge becomes "today" and may be used by the public.

The evolution of knowledge is an iterative process. Depending on the knowledge of frequency witch be very different. Knowledge can be changed in very short periods of time.

\section{PROCESS APPROACH TO KNOWLEDGE MANAGEMENT}

In a process approach the following are taken into account by G. Prost, S. Raub, K. Romhardt:

- locating knowledge,

- acquisition knowledge,

- developing knowledge,

- preserving knowledge,

- $\quad$ sharing knowledge,

- $\quad$ using the knowledge (Fig. 4)[11] [7]

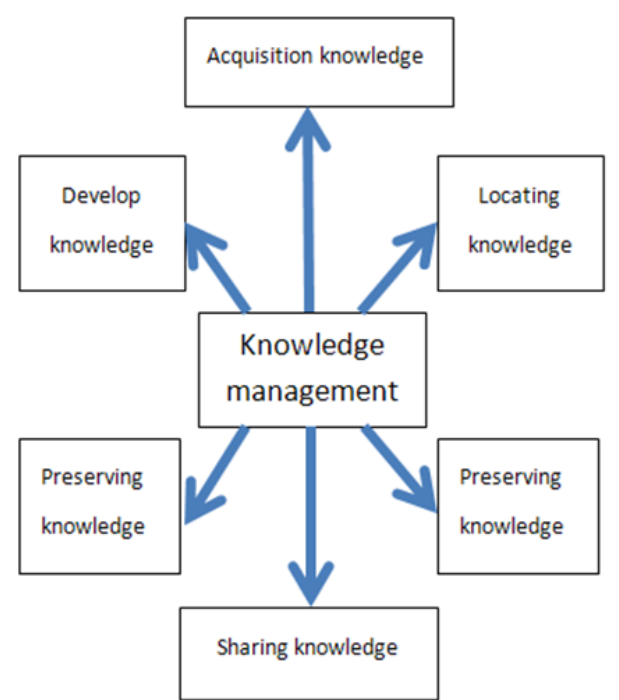

Fig. 4. Elements of knowledge management Source: Own study [11]
Locating of knowledge - a basic function of solving the above problems. However, you will notice that the users in defining the demand for expertise in early stage have very big problems with identifying what knowledge they need.

Acquisition knowledge - knowledge can come from different sources. Each of the entities in the end generates a knowledge of the differentiated value.

Developing knowledge - it is the process of acquiring complementary expertise. The mere knowledge acquisition over time due to turbulence of the environment can lead to stagnation of the acquired knowledge.

Preserving knowledge - can work the right tools and means of media in order to replay, as well as activities undertaken in the field of detention experienced and skilled employees, as the most severe form of loss.

Sharing knowledge and its dissemination - this is one of the most difficult processes of knowledge management. Because of the development of the information society consciousness more and more we appreciate its value.

Using the knowledge - is a process that is used to achieve the objective of the organization. The organization wanting to accomplish their goal should seek to use the findings obtained.

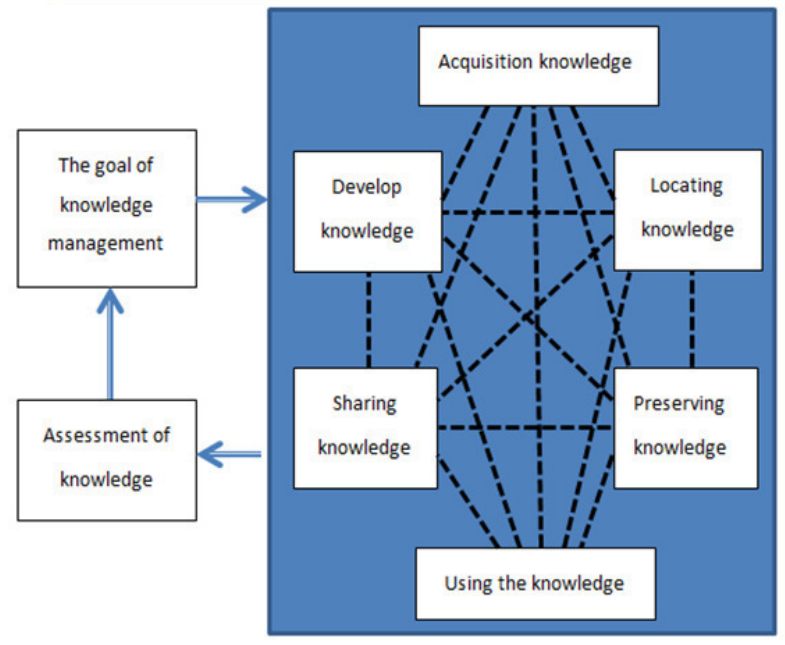

Fig. 5. Knowledge management environment Source: Own study [11]

The activation of any of the six elements determines the assessment of knowledge. If the assessment of knowledge is inadequate to the knowledge of the environment it must be restored to its desired state - founded at the beginning of the creation of educational material.

The proposed approach will allow for an immediate reaction on outdated knowledge in the e-learning system.

\section{LCMS AS AN EXAMPLE OF A PROCESS APPROACH TO MANAGERIAL KNOWLEDGE MANAGEMENT}

Learning Content Management System (LCMS) is a software application that allows content management training. The LCMS helps you to create, use, locate, deliver, manage and improve training content. 
The LCMS is able to locate and deliver to the end user the personalized training unit to cater to a single request, or to provide more elements of the course. Fig. 6 shows the managerial knowledge management process through elearning system - Learning Content Management System (LCMS) [8].

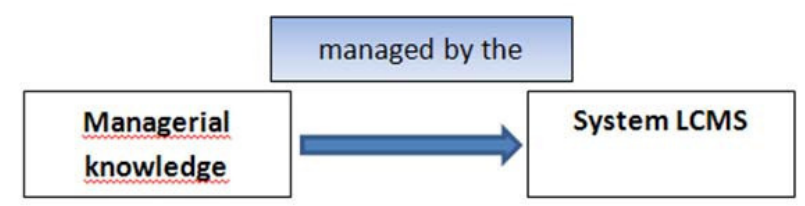

Fig. 6. Knowledge management environment

Source: Own study

Each course is a complex system, which (in the design) can be divided into small separate objects, called "learning objects" and that after the merge create the course content. Fig. 6 shows how you can create repositories managerial knowledge specific to the operating level, management and strategic management of the organization [6].

The basic components of the system LCMS are:

- Repository of learning objects - it is a centralized database in which content knowledge are stored and managed. Content can be made available to users as a single object of knowledge, in the form of larger modules or as an entire course, according to individual requirements.

- $\quad$ Automated authentication application - it is used when creating reusable learning objects, which are available from the repository using templates containing scenarios, training design principles. It supports both authors, slingshots automates the development of learning objects.

- Dynamic publishing interface - provides learning objects based on profiles, preliminary tests and / or user queries.

- $\quad$ Administration - it is used to manage lists of users sharing directories courses with courses, tracking and reporting the progress of the participants [9].

Functional modules of LCMS (Learning Content Management System):

- The object repository - the module object repository is a central database in which are stored all the elements included in the course. From this place objects that make e-learning training they are sent to the students.

- The module automates build courses - in this module to create the objects included in the rate (SCO Sharable Content Objects) module facilitates work by providing templates, as well as the full list of existing objects. which can be re-utilization, processed, copied.

- The distribution of courses - foreign distribution module allows you to share courses to students according to established profiles. It also allows you to track the progress of the trainee and reports the results of exercise testing questions.
- Administration module - it is used to manage the process of learning: account management trainees, providing them with courses, tracking the progress of science and carry out other administrative tasks [10]. The following figure (Fig. 8) shows the overall process of creating the course.

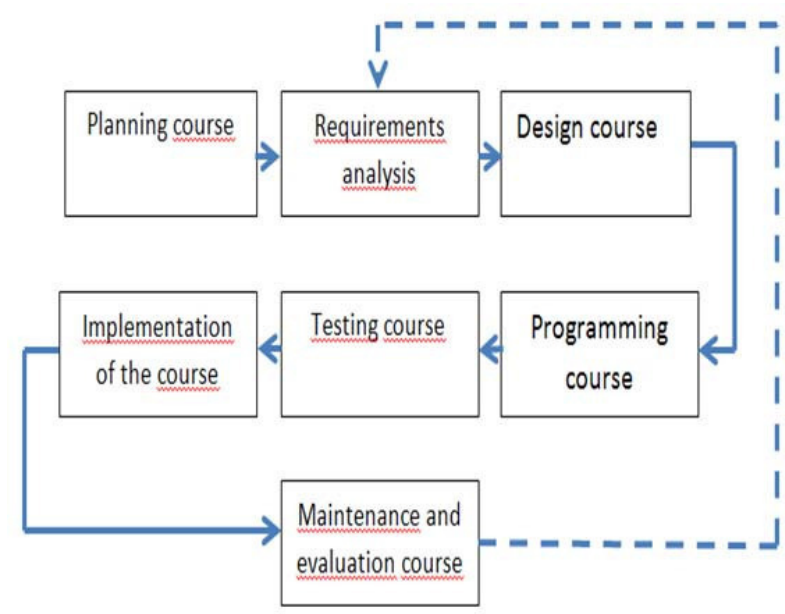

Fig. 8. The process of creating e-learning course Source: Own study

In the process of building the e-learning course we should use the LCMS system. It will help to support the knowledge management function. Thanks to this course it will be able to quickly adapt to changes resulting from the dynamics of the environment. The figure below illustrates the LCMS system in the environment of knowledge management functions.

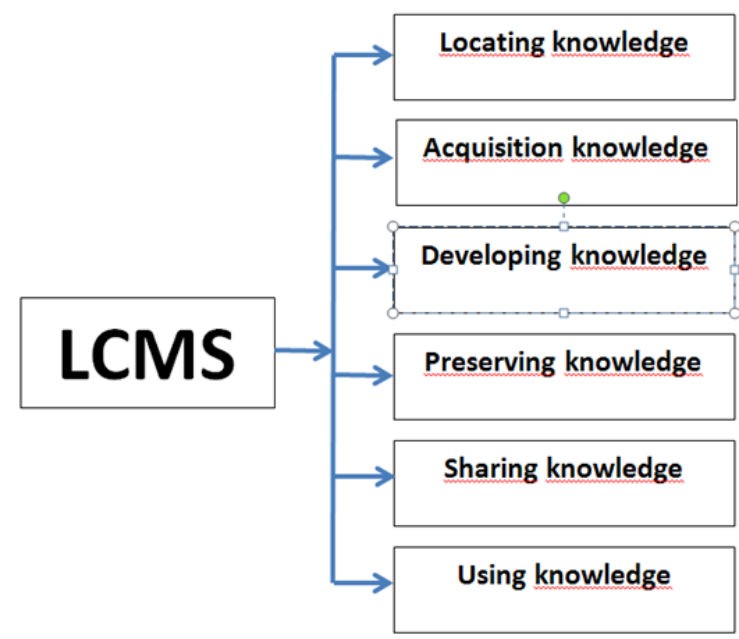

Fig. 9. LCMS in an environment of knowledge management function

Source: Own study

The following analysis will be carried out to present the LCMS system due to the components.

Components - Repository of learning objects - of the system LCMS supports:

- locating knowledge, 
- $\quad$ acquisition knowledge,

- developing knowledge,

- preserving knowledge,

- sharing knowledge,

- using knowledge.

Components - Automated authentication application of the system LCMS supports:

- locating knowledge,

- $\quad$ acquisition knowledge,

- developing knowledge,

- preserving knowledge,

- sharing knowledge,

- using knowledge.

Components - Dynamic publishing interface - of the system LCMS supports:

- acquisition knowledge,

- preserving knowledge,

- using knowledge.

Components - Administation - of the system LCMS supports:

- $\quad$ acquisition knowledge,

- develop knowledge,

- preserving knowledge,

- sharing knowledge,

- using knowledge.

The above analysis shows that the available LCMS system components can support knowledge management functions. As a result, knowledge management may be exercised by the systems to create e-learning courses, a mentor will be able to deal with the domain expertise in educational materials.

\section{CONCLUSION}

Construction of knowledge and placing it in a repository that will be available to designers of e-learning will increase the quality of available educational materials. The disadvantages of data content in materials can be eliminated through a change in approach to lectures created. But it is not only the substantive dimension which must be taken into account. Although it is the most important. You should also pay attention to the efficiency of particular emphasis on funding. Stephen Downes in his work made a very simple economic calculations. These calculations should be taken into account by the designers of courses and organizations that are involved in creating e-learning courses.

These calculations are very simplistic but illustrate the scale of the economic problem. If you prepare one lesson which costs $\$ 100$ and it will be used by 100 universities then the cost of this unit will be $\$ 1$. If, however, the same teaching unit will be produced for each institution individually, the combined cost will be 10000 \$.

Financial calculations, however, should be in the background. Nothing can replace well-designed educational material with current professional knowledge. Recipients quickly assess the value of training that will be fully up to date, discussed the current problems of reality [9].

Managerial knowledge management is very difficult. Its variability over time is the cause of failure of e-learning in the process of transferring knowledge to the recipient. This can be eliminated by a proper design of such a course. The inclusion of knowledge management functions will create the course, which will be able to quickly incorporate the changes in the domain knowledge from the environment.

The use of a process approach to managerial knowledge management can contribute to the improvement of the course prepared for the recipient. Taking into account this approach with the capabilities of the system Learning Content Management Systems - LCMS implemented the tools to build the course which will help to improve the quality of substantial exchange of managerial knowledge.

\section{REFERENCES}

[1] Clarke A., 2007, E-learning nauka na odległość, Klebanowski M. (thum), Wydawnictwo Komunikacji i Łączności, Warszawa.

[2] Dąbrowski M., Zając M.(red.), 2013: Rola e-edukacji w rozwoju kształcenia akademickiego, FPAKE, Warszawa.

[3] Hauke K., Owoc M.L., Schreurs J., Theunissen M., 2000, A multimedia Warehouse Supporting on line learning via Internet, Antwerp, Belgium.

[4] Hauke K., Owoc M.L., Gładysz T., 2001, Management of the Multimedia LearnigSpace, rozdział w Knowledge Acquisition and distributed learning in resolving managerial issues, red: Baborski A., Bonner R., Owoc M.L., Malardalen University (Sweden).

[5] Horton W., 2001: Designing knowledge object - Crafting reusable component for teaching, communicating, and entertaining, William Horton Consulting.

[6] Neven F., Duval E., 2002, Reusable learning objects: a survey of LOM-based repositories, Proceedings of the tenth ACM international conference on Multimedia.

[7] Nycz M. (red.), 2004, Generowanie wiedzy dla przedsiębiorstwa metody I techniki, Wydawnictwo Akademii Ekonomicznej im. Oskara Langego we Wrocławiu, Wrocław.

[8] Hauke K., 2014, Analiza wybranych polskich portali wiedzy wspomagających proces prowadzenia działalności gospodarczej, monografia: Wiedza w kreowaniu przedsiębiorczości, red: Kazimierz Perechuda, Iwona Chomiak- Orsa, Politechnika Częstochowska Wydział Zarządzania, Częstochowa.

[9] Hauke K., 2015, Zarys koncepcji zarządzania obiektami wiedzy menedżerskiej W systemach nauczania na odległość., monografia: Wykorzystanie potencjału współczesnych technologii informacyjnych w zarządzaniu organizacjami, red: Leszek Kiełtyka, Waldemar Jędrzejczyk, Wydawnictwo Politechniki Częstochowskiej, Częstochowa.

[10] Hauke K., Obiekty wiedzy w procesie nauczania na odległość wybrane problemy, monografia: Informatyka 2 Przyszłości, Wydawnictwo Naukowe Wydziału Zarządzania Uniwersytetu Warszawskiego, Warszawa.

[11] Probst G., Raub S., Romhardt K., 2000, Managing Knowledge. Building Blocks for Success, John Wiley \& Sons.

[12] Internet portal: http://www.cedma.org/ [2015.05.05].

[13] Institute Electronic \& Electrical Engineers Learning Technology Sub Committee (IEEE LTSC) L'Allier J., Frame of reference: NETg's Map to the Products, Their Structure and Core beliefs, http://www.netg.com/research/whitepapers/frameref.asp [2015.05.05].

[14] Internet portal: http://forumakad.pl/archiwum/2005/02/15-zakrazace_obiekty_wiedzy.htm [2015.05.05]. 